\title{
日枝神社・根津神社の建築構成とその位置付けについて A STUDY ON ARCHITECTURAL COMPOSITION AND ITS POSITION OF HIE SHRINE AND NEZU SHRINE
}

\author{
加藤千晶 ${ }^{* 1}$, 重枝 豊 ${ }^{* 2}$ \\ Chiaki KATOH and Yutaka SHIGEEDA
}

\begin{abstract}
This paper pays attention to the main sanctuaries of Hie shrine and Nezu shrine are similar to Tosho-gu, clarify the architectural characteristics of both shrines, through comparison with Gongen-style built in Tosho-gu and the shrines other than Tosho-gu, before the Shoo era. Through analysis, it is found that both shrines are buildings that adopting status expression of the stone hall type Gongen-style in votive offering hall type Gongen-style. It become clear that a portion of back ground to collapse combination of main sanctuary and the building between main sanctuary and worship hall, and status expression example of Gongen-style.
\end{abstract}

Keywords : Gongen-style, Hie Shrine, Nezu shrine, composite shrine building, Edo-era 権現造, 日枝神社, 根津神社, 複合社殿, 江戸時代

\section{1. はじめに}

豊国神社に始まる権力者を記念寸る神社兼霊廟の建築は、北野天 満宮にみられる入母屋造の本殿と拝殿とを石の間で繋いだ仏堂建築 に近い社殿形式を取り入れたもので、後に東照宮へと繋がっていっ た。東照宮に普及した形式であることから、明治の頃から「権現造」 という名称で呼ばれている注1)。豊国神社が造営された当時は、この 建築形式を「宮寺作リ」(『匠明』) と呼んだり、また前後に並ぶ平入 りの本殿と拝殿の屋根に両下の屋根を直行にかけた複雑な屋根形態 を形容し、「八棟作り」(『義演准后日記』）と呼んでいた注 2 )。

寛永期には、鶴岡八幡宮若宮や伊賀八幡宮、六所神社など、本殿 を流造とする形式の権現造（準権現造注 3 ）とも呼ばれる）があらわ れた。この形式では、本殿・扯殿間は幣殿と呼ばれる床を拝殿と同 高に張った妻入りの建物になっている。濱島正士注 4) は、「本殿を流 造とすることで権現造より簡略な形式として、より神社的な形式と して、あるいは江戸周辺では家康を祀る東照宮を憚った形式として、 用いられたのではなからうか。と述べている他、麓和善 $\left.{ }^{4}\right)$ は、「単 純に屋根形式のみからいえば入母屋造が最も格が高いので、鈴木長 次の時代にすでに東照宮を慮って、(中略) 複合社殿としながらも本 殿を流造としたと考えられる。と述べているように、東照宮よりも 格を落とした権現造として成立したと考えられている。

流造は、中世において神社に最も普及した本殿形式である。また、 中世以降、本殿正面に妻入の縦择殿あるいは幣殿を接近させて建て る社頭がみられる注 5)。

桃山時代以降には柏原八幡神社や富士山本宮浅間大社など秀吉や
家康による社殿の複合化の流れが起き、秀忠・家光の治世に入って からは東照宮の影響の下、前述の中世以降の社殿の要素を八棟造の 形態を取り入れる形で構成したことで、鶴岡八幡宮若宮のような複 合社殿の形式が成立したと考えられる。鶴岡八幡宮若宮と同形式の 権現造は、幕府成立の時期よりも創建が古い神社に造営された。東 照宮のような八棟造の形態を取り入れたのは、一般の神社であった のを徳川家の神社として造りかえることを意図していたと考えられ る注 6 。

家綱治世以降に建立された日枝神社（戦災焼失）と根津神社の本 殿は、東照宮に似た方 3 間入母屋造である。このことは、東照宮以 外の神社に建てられた権現造に、それまで東照宮にしか用いられな かった形式が取り入れられていったことを示している。

\section{2. 既往文献における日枝神社及び根津神社の評価}

日枝神社について、『東京府史蹟』6)、大熊喜邦「市内に於ける史 蹟保存としての建築物」7)、旧国宝建造物指定説明（昭和 6 年）で 述べられている建物の評価に関する要点をまとめると、(1)鈴木長 恒・木原義永両氏の設計であること、(2)権現造であること、(3)（都 内の) 現存神社中最も優れたものの一つであること、(4)江戸初期神 社建築の代表的遺例であることが共通して挙げられており、大熊は さらに内部の装飾に見るべきものがあるとしている。内藤昌 8) は、 「総体に桃山の華麗な様式を脱した感があり、明暦大火後の建築と して注目してよからう。」として、当時の装飾表現や時代背景につい ても評価している。また社殿の結構が徳川家の産土神として厚い崇
$* 1$ 日本大学理工学部建築学科 助手 $\cdot$ 工修

*2 日本大学理工学部建築学科 教授. 工博 
敬もあり、江府一の宮居とされたことについても言及している。

根津神社については、『東京府史蹟』6) 及び大熊（同前）は、その 様式が「普通の権現造」であり、その代表的建築の一つということ や、江戸後期を代表する神社建築の唯一の遺例であることが述べら れている。また、修理工事報告書 9) では、幣殿の長さが時代の特徴 をよくあらわしていることや、「江戸期に完塗（成力）された木割手 法、統一された成（塗力）色分け、要所に飾られた、彫刻と彩色、 装飾具が渾然一体となって、軸部の構成を侵すことなく、簡素の内 にもまとまった美しさを現わしている。」と述べるように建物の意匠 的調和についても評価している。

明暦大火後の再建によって「江府第一の宮居」(『江戸名所図会』) と評されてきたように、日枝神社は既往文献においても都内の現存 神社中最も優れたものの一つであることを認めており、根津神社は 時代が下るためか日枝神社に次いで評価されている。しかしながら、 江戸時代にいかなる建築表現が日枝神社を「江府第一の宮居」たら しめていたかは明解でなく疑問が残る。

伊東忠太は「日本神社建築の発達(下)」1) の中で、権現造にも色々 形の異なるものがあり、その平面や外形について、中殿の床高や、 拝殿、本殿の屋根形状から区別でき、それらの組み合わせによって 幾多の種類ができる理窟であると述べているように、各神社の修理 工事報告書や各都府県の近世社寺建築緊急調查報告書をみると、全 国に現存する権現造の造形は多様である。ただし、徳川家光死去直 後の承応期までに幕府が造営した権現造を見ると、東照宮において は石の間・本殿入母屋造、御霊屋注 7)においては廊下・本殿入母屋 造裳階付、東照宮以外の神社においては、幣殿・本殿正面庇莫下し （主に流造）の構成が基本となっているように注8)、いわゆる中殿と 本殿が特定の組合せになっている。日枝神社・根津神社は、いわゆ る中殿と本殿の組合せが形式化していた権現造の構成が崩れていく 過渡的状況を示寸事例として位置付けられる。日枝神社の本殿が東 照宮と似た形式となっていることは既往文献には触れられていない が、同神社が明歴大火後の復興により「江府第一の宮居」となった ことと関係するとみられ、また日枝神社の建築が後の根津神社の建 築に影響を与えたものと推察される。

\section{3. 研究目的及び方法}

本稿は、日枝神社・根津神社の建築的特徵を明らかにし、両社の 建築史上の位置付けを行うことを目的とする。

そのため、まず、幕府が承応期以前に造営した東照宮と東照宮以 外の神社の権現造について、両者の構成や意匠の違い、本殿形式に よる軒の納まりの設計手法の違いを検討する。明治時代に取り壊さ れた紅葉山東照宮（承応 3 年・1654）の建築の情報は、都立中央図 書館と国立公文書館に所蔵されている図面（江戸時代作成）によっ て補い、修理工事報告書が公刊されていない鶴岡八幡宮若宮につい ては現地調查を行った。

次に、日枝神社・根津神社の建築について、承応期以前に造営さ れた東照宮及び東照宮以外の神社の権現造にみられる構成や意匠の 特徴をどのように選択し用いているか分析を行う。また、軒の納ま りの設計手法について、承応期以前のものと比較しながら検討する。 日枝神社の建築は戦災で焼失したため、焼失前の建物の情報は、 『国宝・重要文化財（建造物）実測図集』東京都（その1）の平面
図や『新版 戦災等による焼失文化財』11)、『東京府史蹟』6)によっ て補う。

以上の分析を通して日枝神社・根津神社の建築的特徴を明らかに した上、幕府が権現造を造営した東照宮以外の神社が幕府にとって どのような位置付けであったか歴史的に考察し、日枝神社・根津神 社の建築の建築史的価值を明らかにしたい。

なお、村上訒一 10) は、本殿を流造とする形式や、霊廟建築（御 霊屋) を「権現造」とするには問題があるとし、総称としては、「複 合社殿」が適切と考えられると指摘しているが、「複合社殿」は鹿島 神宮のように幣拝殿と本殿を石の間で繋ぐ形式や、日御碕神社のよ うに凸型平面をもつ幣拝殿に独立した本殿を接近させる形式等にも 用いられる。本稿ではそれらと便宜的に区別するため、本殿と拝殿 とを、石の間や幣殿、廊下などで接続した複合社殿を総称して権現 造と称することとする。また、本稿でいう幕府造営の事例とは、将 軍が願主となって造営に出資したものの内、幕府の大工が造営に携 わったことが記録等で確認できるものに限ることとする。

\section{4. 本殿・拝殿間の形式、本殿屋根形式による分類}

まず、幕府が東照宮及び東照宮以外の神社に造営した権現造の事 例について、本殿・拝殿間の形式と本殿屋根形式によって分類し、 整理しておきたい。本殿・拝殿間の形式については、本殿及び扯殿 よりも床の低いものを石の間、床が拝殿と同高または拝殿よりも一 段高いものを幣殿としている。石の間は石敷きの間を意味するが、 本殿と拝殿の間を壁と屋根で塞いでできた名残を示す床の低い空間 を指して用いている。幣殿とは幣帛を供進するための建物を意味す るが、「殿」は、本殿、拝殿、舞殿など、ある機能を持った建物の呼 称に付くもので、現在鶴岡八幡宮若宮や伊賀八幡宮等で幣殿と呼ば れている部分は、壁と屋根で覆われてできた石の間に比べて建物と しての存在感が強く注 9)、幣殿を拝殿に転化したと考えられている縦 拝殿に近いことからも ${ }^{5)}$ 、通称通り幣殿と呼ぶこととする。

分類した平面図を時系列に並べた（fig.1）。東照宮と東照宮以外 の神社の大きな違いは、本殿・拝殿間を石の間とするか、幣殿とす るかである。石の間十本殿入母屋造の形式の東照宮は、豊国神社を はじめとする慶長期の流れを波んでおり、元和 3 年 (1617) 久能山 東照宮から承応 3 年 (1654) 紅葉山東照宮まで古式を保っていたこ とがわかる。東照宮以外の神社の内、寛永期のものは、幣殿十本殿 流造（正面庇下に階があるものと、床を張って前室とするものが女 る）の形式と、幣殿+本殿入母屋造向拝付注 10) の形式の二種類であ る。本殿入母屋造向拝付は五社神社の 1 棟で、本殿流造が圧倒的に 多い。承灾期以前の東照宮以外の神社では幣殿は本殿身舎から莫き 下ろした庇に接続するのが特徴といえる。東照宮以外の神社におい て入母屋造の本殿が現れるのは三芳野神社が建てられた明暦以降で ある注11。

以下からは、東照宮において典型的な石の間をもつ権現造を石の 間型権現造、東照宮以外の神社において典型的な幣殿をもつ権現造 を幣殿型権現造として論を進めることとする。

\section{5. 承応期以前の石の間型権現造と幣殿型権現造の構成の比較}

\section{5-1. 拝殿について}

扯殿には、単室とするものと、内部を建具で仕切るものがある。 


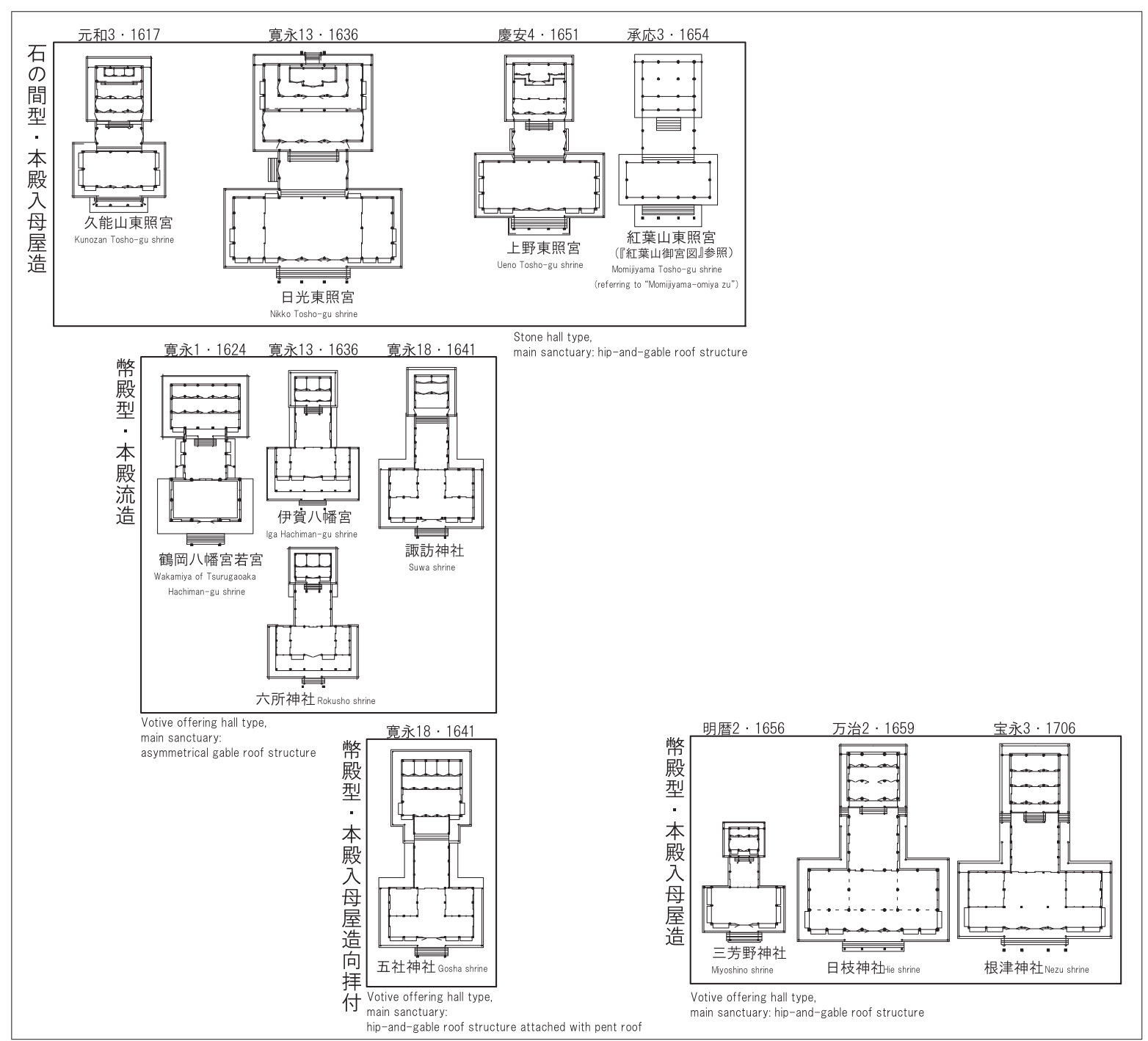

Fig.1 The classification of plan and their changes through the ages of Gongen-style buildings constructed by Shogunate:

Tosho-gu and the shrines other than Tosho-gu.

幕府造営の権現造（東照宮及び東照宮以外の神社）の平面の分類と年代推移

永井規男注 ${ }^{12)}$ は、久能山東照宮にみられる単室構成の帱殿形式は、 ひとつの定型として近世を通じて各地の権現造に採用される一方、 大崎八幡宮のように、内部に仕切りをもつ小室をつくるものが早く からあり、梁間全体にわたる明確な仕切りは寛永度日光東照宮にお いてはじめて行われたとする。また、六所神社・伊賀八幡宮帱殿は、 日光東照宮拝殿を縮小し、その前に 1 間通りの吹き放ちを付け足し た平面であり、この吹き放ちを室内に取り込んだのが五社神社・諏 訪神社の平面で、根津神社に受け継がれるとする注 ${ }^{13)}$ 。

择殿内部を建具で仕切る事例は、石の間型権現造では日光東照宮

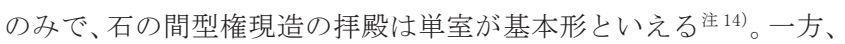
幣殿型権現造では鶴岡八幡宮若宮を除く全ての事例で見られる。日 光東照宮において成立した三室構成は、石の間型権現造では引き継 がれなかったが、幣殿型権現造において発展をみせたといえる。

柱間装置については、石の間型権現造では、正面中央 3 間を栈唐 戸とするほか、正面両脇と側面を蔀戸、背面板壁とする。幣殿型権 現造では正面中央間を栈唐戸、正面両脇を蔀戸とし、残りの側迴り と内部間仕切を舞良戸とするように、石の間型に比べて舞良戸を多
用している。また、扯殿と石の間または幣殿境は、石の間型権現造 では吹放ちとするが、幣殿型権現造では格子の引戸を入れて仕切る といった違いがみられる。

正面向拝は、石の間型権現造では 3 間とするのに対し、幣殿型権 現造では 1 間である。幣殿型権現造は石の間型権現造を憚って、向 扯の幅を小さくしているとみられる。

\section{5-2. 石の間、幣殿について}

石の間、幣殿の間口は、本殿の正面が 2 間幅の諏訪神社を除き、 すべて本殿桁行中央 3 間と同幅である。慶長期の権現造では石の間 間口が 5 間または 7 間であり、横長平面となるが、江戸時代以降、 石の間、幣殿ともに本殿正面中央 3 間幅が定着する。

石の間では桁行各間の寸法が異なり、中央に唐戸口を設け、その 両側を壁でふさぐ。石の間前方 2 間の柱を拝殿と同高に揃えて桁行 に頭貫を通すため、遅殿と石の間前方 2 間は凸型平面の一体化した 構造となる。石の間後方 1 間は、本殿と石の間前方 2 間の構造との 間にできた作り合い注 $\left.{ }^{15}\right)$ になる。作り合いの間隔は本殿軒出よりも 大きい。日光東照宮と紅葉山東照宮になると、作り合いに海老虹梁 


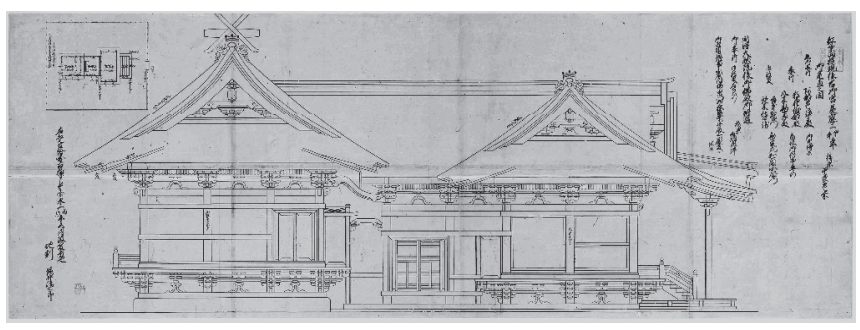

Fig.2 'Momijiyama-omiya zu' (Tokyo Metropolitan Library) 「紅葉山御宮図」都立中央図書館蔵
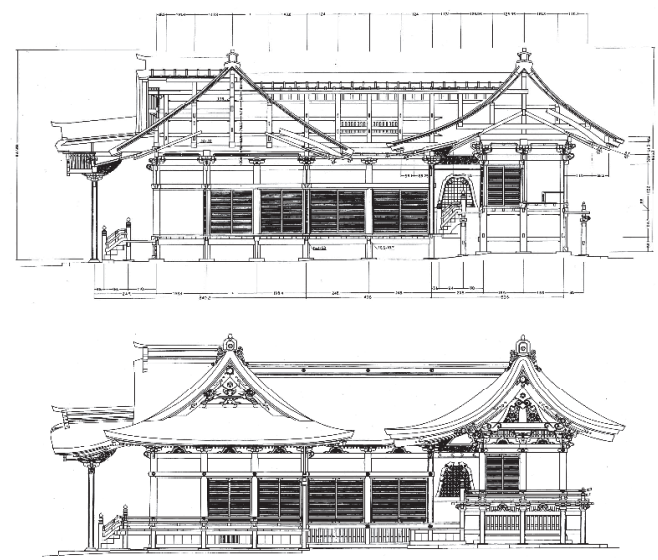

Fig.3 Section and elevation of Rokusho shrine. (Reference 22, Drawing 3 and 5.)

六所神社断面図・側面図（参考文献 22, 図面 3, 5)
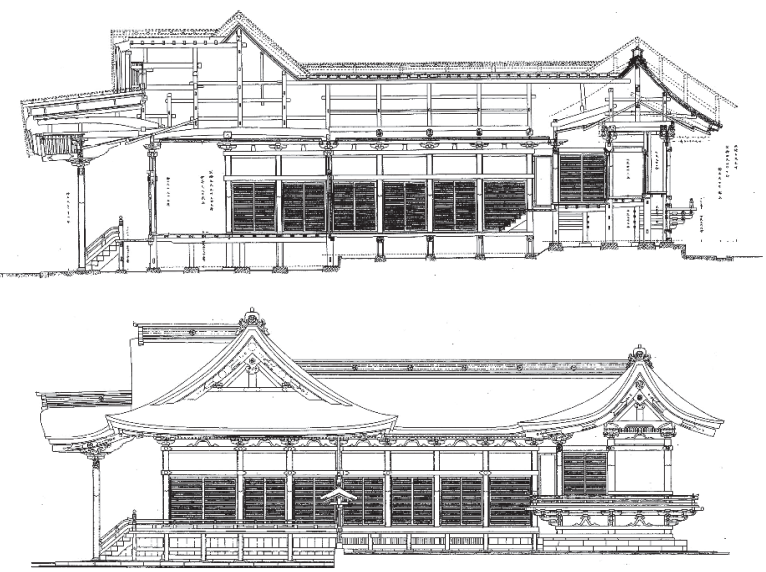

Fig.4 Section and elevation of Suwa Shrine before the fire.

(Reference 3, p62, 95.)

諏訪神社焼失前断面図 - 側面図（参考文献 3, p62, 95）
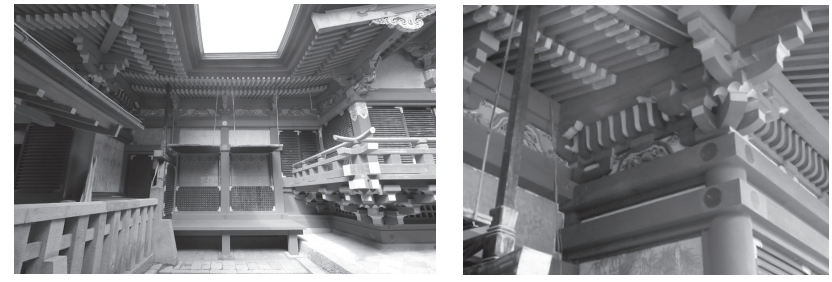

(右側本殿・中央幣殿・左側扯殿)

(右拝殿・左幣殿)

Photo1 Wakamiya of Tsurugaoka Hachiman-gu Shrine. 鶴岡八幡宮若宮
を架け、本殿と石の間前方 2 間の構造を繋ぐようになる（Fig.2）。

上野東照宮は例外で、本殿・石の間・扯殿の柱頂部の高さを揃え て外周すべてに頭貫を通し、本殿・石の間・拝殿の構造を一体化し てつくる。

幣殿は桁行の各間が等間隔である注 16)。幣殿の桁行方向の柱筋は、 拝殿の柱筋とずれるため、拝殿背面に幣殿の半柱を立てる。

永井規男の論考注 17）では、権現造の幣殿（ママ）には北野天満宮 や日光東照宮などの石の間型と台徳院霊廟の相の間型とがあり、相 の間型では拝殿と幣殿は床高を同じにするだけでなく、立面構成も ほぼ同じにつくるとする注 ${ }^{18)}$ 。

実際に幣殿の立面構成をみると、伊賀八幡宮、六所神社、五社神 社、諏訪神社では、拝殿と同じ高さに頭貫、内法長押、切目長押を 通し、両側面に扯殿側面と同じ建具（舞良戸）を入れるなど、拝殿 と一連の立面構成になっている (Fig.3，4）。伊賀八幡宮、六所神社、 五社神社の幣殿後方の柱はそのまま本殿正面庇の柱となっているが (Fig.3)、諏訪神社の幣殿は、本殿前室前方の縁までであり、本殿 と幣殿との間は、前室前方の縁幅分の作り合いとなる (Fig.4)。

一方、鶴岡八幡宮若宮では、幣殿床高を扯殿よりも一段高くする。 幣殿の立面も、幣殿頭貫及び台輪長押が本殿前室の頭貫及び内法長 押と連続し、扯殿とは柱高や長押位置が揃わない。また、幣殿桁行 中央 2 間に本殿前室正面と同じ建具 (半蔀)を入れる注 19) $(P h o t o 1) 。$ 伊賀八幡宮・六所神社以降、幣殿は拝殿と一連とした造りとなるの に対し、鶴岡八幡宮若宮幣殿は本殿前室から続く構造になる。そこ で、幣殿型権現造の幣殿桁行の 1 枝寸法についてみると（Table1）、 鶴岡八幡宮若宮の幣殿桁行の 1 枝寸法は本殿と等しいのに対し、伊 賀八幡宮、六所神社、五社神社、諏訪神社の幣殿桁行の 1 枝寸法は 拝殿と等しい注 20)。このことからも、鶴岡八幡宮若宮の段階では、 まだ、幣殿が本殿前室から続く構造であったことが裏付けられる。 幣殿の立面構成を拝殿と一連とする形式は、寛永 13 年の伊賀八幡 宮と六所神社以降定型化したといえる。

また、幣殿はいずれも本殿正面庇に接続するため、内部に本殿正 面庇を装飾する頭貫注 21 ) や中備が見えているのが特徵である (Photo2)。

\section{5-3. 斗栱}

本殿、石の間・幣殿、拝殿の斗栱の種類を検討する（Table2）。 斗栱の手先数をみると、本殿は、石の間型権現造では二手先以上、 幣殿型権現造では一手先である。石の間・幣殿、拝殿は、石の間型

Table1 An interval between the rafters of ridge direction of worship hall.

幣殿桁行の 1 枝寸法

\begin{tabular}{l|c|c|c}
\hline \multirow{4}{*}{$\begin{array}{l}\text { 建物 } \\
\text { Building }\end{array}$} & \multicolumn{3}{|c}{$\begin{array}{c}\text { 1枝寸法(寸) } \\
\text { An interval between the rafters (sun) }\end{array}$} \\
\cline { 2 - 4 } & $\begin{array}{c}\text { 本殿 } \\
\text { Main sanctuary }\end{array}$ & $\begin{array}{c}\text { 幣殿 } \\
\text { Votive offering hall }\end{array}$ & $\begin{array}{c}\text { 拝殿 } \\
\text { Worship hall }\end{array}$ \\
\hline $\begin{array}{l}\text { 鶴岡八幡宮若宮 } \\
\text { Wakamiya of Tsurugaoka } \\
\text { Hachiman-gu shrine }\end{array}$ & 5.0 & 5.0 & 5.833 \\
\hline $\begin{array}{l}\text { 伊賀八幡宮 } \\
\text { Iga Hachiman-gu shrine }\end{array}$ & 3.75 & 5.0 & 5.0 \\
$\begin{array}{l}\text { 六所神社 } \\
\text { Rokusho shrine }\end{array}$ & $\begin{array}{c}3.748 \\
\text { (析行中央間3.796) } \\
\text { (A central bay in lenth) }\end{array}$ & 4.092 & 4.092 \\
\hline $\begin{array}{l}\text { 五社神社 } \\
\text { Gosha shrine }\end{array}$ & 4.5 & 4.643 & 4.643 \\
\hline $\begin{array}{l}\text { 諏訪神社 } \\
\text { Suwa shrine }\end{array}$ & 3.755 & 4.65 & 4.65 \\
\hline
\end{tabular}




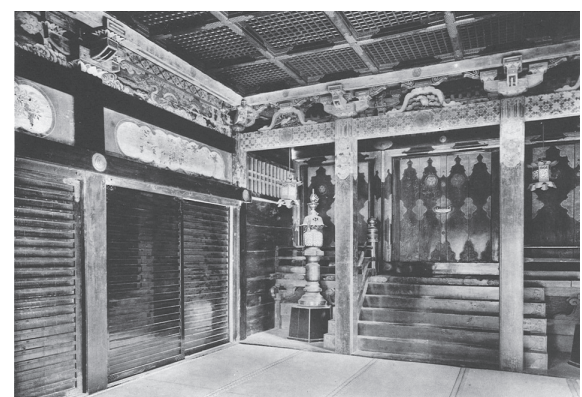

Photo2 Interior of the votive offering hall

of Iga Hachiman-gu Shrine. (Reference 21, Picture18.)

伊賀八幡宮幣殿内部（参考文献 21 , 第 18 図）

権現造では一手先以上、幣殿型権現造では、鶴岡八幡宮若宮が幣殿 を出三斗、据殿を出組とする以外はすべて平三斗である。斗栱の手 先数は、幣殿型権現造よりも石の間型権現造の方が多いことがわか る。流造本殿をもつ権現造が東照宮を憚った形式といわれている通 り、本殿を流造とする権現造は石の間型権現造より組物の格を落と して設計されている。入母屋造向拝付の五社神社もその他幣殿型権 現造と同じ組物を用いることから、幣殿型権現造は本殿の屋根形式 に関わらず、石の間型権現造よりも組物の格式を落として設計がな されたことがわかる。

\section{5-4. 柱断面形状}

本殿、石の間・幣殿、拝殿の柱断面形状について検討する $(\mathrm{Tab} 1 \mathrm{e} 2)$ 。 石の間型権現造は総円柱とするのに対し、幣殿型権現造では本殿を 円柱 (正面庇または向扯は角柱)、帱殿・幣殿を角柱とする場合が多 い。幣殿型権現造では引違戸を多用することから、戸の納まりの都 合上角柱が用いられたとみられる。仏堂風の要素が強い石の間型権 現造に比べ、幣殿型権現造の幣殿・拝殿は住宅風の要素が多用され ているといえる。また、角柱の角を落として製材する円柱は、角柱 に比べ格式が高いことからみて、幣殿型権現造では石の間型権現造 を憚って角柱を用いたものが多かったといえる。幣殿型権現造で幣 殿・拝殿に円柱を用いている二社の内、鶴岡八幡宮若宮は、立面構 成や組物の形式が他の幣殿型権現造と異なっているため例外として、
Table3 Other examples having the innermost fence type $\mathrm{X} / \mathrm{Y}$. タイプ X, Y の形式を持つその他事例

\begin{tabular}{|c|c|c|}
\hline & 建物名 Building & 備考 Notes \\
\hline \multirow{10}{*}{$X$} & 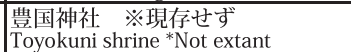 & $\begin{array}{l}\text { 「豊国神社 祭礼図屏風」 (豊国神社宝物館蔵) } \\
\text { " Toyokuni Sairei zu Byobu" (Toyokuni ShrineTresure House) }\end{array}$ \\
\hline & $\begin{array}{l}\text { 名古屋東照宮 ※現存せず } \\
\text { Nagoya Tosho-gu shrine *Not extant }\end{array}$ & $\begin{array}{l}\text { 文化庁『新版 戦災等による焼失文化財』 } \\
\text { (Reference 11) }\end{array}$ \\
\hline & $\begin{array}{l}\text { 紀州東照宮 } \\
\text { Kishu Tosho-gu shrine }\end{array}$ & $\begin{array}{l}\text { ※ただし本殿背面には瑞垣は迴らない } \\
\text { *Provided that there is not the back of the innermost fence. }\end{array}$ \\
\hline & $\begin{array}{l}\text { 水戸東照宮 ※現存せず } \\
\text { Mito Tosho-gu shrine *Not extant }\end{array}$ & $\begin{array}{l}\text { 田邊泰「水戸東照宮の建築第」(『早稲田建築学報』 } \\
\text { Tharabe, Architecture of Mito Tosho-gu, Waseda Architecture } \\
\text { informatics. No.12. }\end{array}$ \\
\hline & $\begin{array}{l}\text { 金地院東照宮 } \\
\text { Konchiin Tosho-gu shrine }\end{array}$ & \\
\hline & $\begin{array}{l}\text { 台徳院霊廟 } \quad \text { ※現存せず } \\
\text { Taitokuin mausoleum *Not extant }\end{array}$ & $\begin{array}{l}\text { 田邊泰『徳川家霊廟』彰国社、1942 } \\
\text { Tanabe, T.: Tokugawa Family Mausoleum, Shokokusha, } 1942 .\end{array}$ \\
\hline & $\begin{array}{l}\text { 日吉東照宮 } \\
\text { Hioshi Tosho-gu shrine }\end{array}$ & \\
\hline & $\begin{array}{l}\text { 日光東照宮仮殿 } \\
\text { Kaden of Nikko Tosho-gu shrine }\end{array}$ & \\
\hline & $\begin{array}{l}\text { 崇源院霊牌所 } \quad \text { ※現存せず } \\
\text { Sugenin mausoleum *Not extant }\end{array}$ & $\begin{array}{l}\text { 田邊泰『徳川家霊廟』 } \\
\text { Tanabe, T.: Tokugawa Family Mausoleum, Shokokusha, } 1942 .\end{array}$ \\
\hline & \begin{tabular}{|l} 
大猷院霊廟 \\
Taiyuin mausoleum
\end{tabular} & \\
\hline $\mathrm{Y}$ & $\begin{array}{l}\text { 三島大社(寛永期) ※現存せず } \\
\text { Mishima shrine (Kannei-era) *Not extant } \\
\text { 飯倉神明社(寛永期) ※現存せず } \\
\text { Iikura Shinmei-sha shrine (Kannei-era) } \\
\text { *Not extant }\end{array}$ & $\begin{array}{l}\text { 寬永11年「三島大社境内図」(三島大社宝物館蔵) } \\
\text { Mishima taisha shrine Keidaia (1634) zu" (Mishima Taisha Tresure House) } \\
\text { 『御府内備考続編』 } \\
\text { (Reference 24) }\end{array}$ \\
\hline & $\begin{array}{l}\text { 相馬中村神社 } \\
\text { Soma Nakamur }\end{array}$ & \\
\hline
\end{tabular}

六所神社で幣殿・扯殿に円柱を用いた理由は、おそらく、同年に同 じ岡崎に建立された伊賀八幡宮と格式の違いを表現しようとしたと 思われる。

\section{5-5. 瑞垣}

社殿に付属する瑞垣について検討する。社殿に付属する瑞垣は、 社殿を囲う方式が二通りである。一つは、拝殿正面に瑞垣門を構え 門両脇から透塀を発するもので、権現造を一周する。もう一つは本 殿及び幣殿を側面、背面の三方から囲うもので、瑞垣は拝殿背後ま たは幣殿側面から発せられる。前者の瑞垣門を構える形式をタイプ $\mathrm{X}$ ，後者の扯殿より後ろから瑞垣を発する形式をタイプ $\mathrm{Y}$ とし、瑞 垣を分類した (Table2)。タイプ X は石の間型権現造に、タイプ Y は幣殿型権現造にみられ、石の間型権現造と幣殿型権現造とで形式 が異なることがわかる。

Table2 以外の権現造で、タイプ X 及びタイプ Y の形式をもつ事 例を調心゙、まとめたのが Table3 である。

Table2 Analysis of bracket complex, sectional shape of columns, and innermost fence, in the stone hall type Gongen-style / the votive offering hall type Gongen-style. 石の間型権現造及び幣殿型権現造の斗栱、柱断面形状、瑞垣形式の分析

\begin{tabular}{|c|c|c|c|c|c|c|c|c|}
\hline & \multirow[b]{2}{*}{\begin{tabular}{|l|} 
建物 \\
Building
\end{tabular}} & \multicolumn{3}{|c|}{ 斗栱 Bracket complex } & \multicolumn{3}{|c|}{ 柱断面形状 Sectional shape of column } & \multirow{2}{*}{$\begin{array}{l}\text { 瑞垣形式 } \\
\text { Innermost } \\
\text { fence type }\end{array}$} \\
\hline & & \begin{tabular}{|c|} 
本殿 \\
Main sanctuary
\end{tabular} & $\begin{array}{c}\text { 石の間,幣殿 } \\
\text { Stone hall, } \\
\text { Votive offering hall }\end{array}$ & $\begin{array}{c}\text { 拝殿 } \\
\text { Worship hall }\end{array}$ & \begin{tabular}{c|} 
本殿 \\
Main sanctuary
\end{tabular} & $\begin{array}{c}\text { 石の間,幣殿 } \\
\text { Stone hall, } \\
\text { Votive offering hall }\end{array}$ & \begin{tabular}{|c|} 
拝殿 \\
Worship hall
\end{tabular} & \\
\hline \multirow{4}{*}{$\begin{array}{l}\text { 石の間型 } \\
\text { The stone } \\
\text { hall type }\end{array}$} & $\begin{array}{l}\text { 久能山東照宮 } \\
\text { Kunozan Tosho-gu shrine }\end{array}$ & $\begin{array}{l}\text { 二手先 } \\
\text { Nitesaki }\end{array}$ & $\begin{array}{c}\text { 出組 } \\
\text { Degumi }\end{array}$ & $\begin{array}{c}\text { 出組 } \\
\text { Degumi }\end{array}$ & $\begin{array}{l}\text { 円柱 } \\
\text { Round }\end{array}$ & $\begin{array}{l}\text { 円柱 } \\
\text { Round }\end{array}$ & \begin{tabular}{c|} 
円柱 \\
Round
\end{tabular} & $\mathrm{X}$ \\
\hline & $\begin{array}{l}\text { 日光東照宮 } \\
\text { Nikko Tosho-gu shrine }\end{array}$ & \begin{tabular}{|c|} 
三手先詰組 \\
Mitesaki-Tsumegumi
\end{tabular} & $\begin{array}{c}\text { 二手先詰組 } \\
\text { Nitesaki-Tsumegumi }\end{array}$ & $\begin{array}{c}\text { 二手先詰組 } \\
\text { Nitesaki-Tsumegumi }\end{array}$ & $\begin{array}{l}\text { 円柱 } \\
\text { Round }\end{array}$ & $\begin{array}{l}\text { 円柱 } \\
\text { Round }\end{array}$ & $\begin{array}{c}\text { 円柱 } \\
\text { Round }\end{array}$ & $\mathrm{X}$ \\
\hline & $\begin{array}{l}\text { 上野東照宮 } \\
\text { Ueno Tosho-gu shrine }\end{array}$ & $\begin{array}{c}\text { 二手先 } \\
\text { Nitesaki }\end{array}$ & $\begin{array}{c}\text { 二手先 } \\
\text { Nitesaki }\end{array}$ & $\begin{array}{c}\text { 二手先 } \\
\text { Nitesaki }\end{array}$ & $\begin{array}{l}\text { 円柱 } \\
\text { Round }\end{array}$ & $\begin{array}{l}\text { 円柱 } \\
\text { Round }\end{array}$ & $\begin{array}{c}\text { 円柱 } \\
\text { Round }\end{array}$ & $\mathrm{X}$ \\
\hline & $\begin{array}{l}\text { 紅葉山東照宮 } \\
\text { Momijiyama Tosho-gu shrine }\end{array}$ & $\begin{array}{l}\text { 二手先力 } \\
\text { Nitesaki }\end{array}$ & $\begin{array}{l}\text { 二手先力 } \\
\text { Nitesaki }\end{array}$ & $\begin{array}{l}\text { 二手先力 } \\
\text { Nitesaki }\end{array}$ & $\begin{array}{l}\text { 円柱 } \\
\text { Round }\end{array}$ & $\begin{array}{l}\text { 円柱 } \\
\text { Round }\end{array}$ & \begin{tabular}{c|} 
円柱 \\
Round
\end{tabular} & $X$ \\
\hline \multirow{5}{*}{$\begin{array}{l}\text { 幣殿型 } \\
\text { The } \\
\text { worship } \\
\text { hall type }\end{array}$} & $\begin{array}{l}\text { 鶴岡八幡宮若宮 } \\
\text { Wakamiya of Tsurugaoka Hachiman-gu } \\
\text { shrine }\end{array}$ & $\begin{array}{c}\text { 出組 } \\
\text { Degumi }\end{array}$ & $\begin{array}{c}\text { 出三斗 } \\
\text { De-mitsudo }\end{array}$ & $\begin{array}{c}\text { 出組 } \\
\text { Degumi }\end{array}$ & $\begin{array}{c}\text { 円柱 } \\
\text { Round }\end{array}$ & $\begin{array}{l}\text { 角柱 } \\
\text { Square }\end{array}$ & $\begin{array}{c}\text { 円柱 } \\
\text { Round }\end{array}$ & $\mathrm{Y}$ \\
\hline & $\begin{array}{l}\text { 伊賀八幡宮 } \\
\text { Iga Hachiman-gu shrine }\end{array}$ & $\begin{array}{c}\text { 出組 } \\
\text { Degumi }\end{array}$ & $\begin{array}{c}\text { 平三斗 } \\
\text { Hira-mitsudo }\end{array}$ & $\begin{array}{c}\text { 平三斗 } \\
\text { Hira-mitsudo }\end{array}$ & $\begin{array}{l}\text { 円柱 } \\
\text { Round }\end{array}$ & $\begin{array}{c}\text { 角柱 } \\
\text { Square }\end{array}$ & \begin{tabular}{|c|} 
角柱 \\
Square \\
\end{tabular} & $\mathrm{Y}$ \\
\hline & $\begin{array}{l}\text { 六所神社 } \\
\text { Rokusho Shrine }\end{array}$ & $\begin{array}{c}\text { 出組 } \\
\text { Degumi }\end{array}$ & $\begin{array}{c}\text { 平三斗 } \\
\text { Hira-mitsudo }\end{array}$ & $\begin{array}{c}\text { 平三斗 } \\
\text { Hira-mitsudo }\end{array}$ & $\begin{array}{l}\text { 円柱 } \\
\text { Round }\end{array}$ & $\begin{array}{l}\text { 円柱 } \\
\text { Round }\end{array}$ & $\begin{array}{c}\text { 円柱 } \\
\text { Round }\end{array}$ & $\mathrm{Y}$ \\
\hline & $\begin{array}{l}\text { 五社神社 } \\
\text { Gosha Shrine }\end{array}$ & $\begin{array}{c}\text { 出組 } \\
\text { Degumi }\end{array}$ & $\begin{array}{c}\text { 平三斗 } \\
\text { Hira-mitsudo }\end{array}$ & $\begin{array}{c}\text { 平三斗 } \\
\text { Hira-mitsudo }\end{array}$ & $\begin{array}{l}\text { 円柱 } \\
\text { Round }\end{array}$ & $\begin{array}{l}\text { 角柱 } \\
\text { Square }\end{array}$ & $\begin{array}{c}\text { 角柱 } \\
\text { Square }\end{array}$ & $\mathrm{Y}$ \\
\hline & $\begin{array}{l}\text { 誀訪神社 } \\
\text { Suwa Shrine } \\
\end{array}$ & $\begin{array}{c}\text { 出組 } \\
\text { Degumi }\end{array}$ & $\begin{array}{c}\text { 平三斗 } \\
\text { Hira-mitsudo }\end{array}$ & $\begin{array}{c}\text { 平三斗 } \\
\text { Hira-mitsudo }\end{array}$ & $\begin{array}{l}\text { 円柱 } \\
\text { Round }\end{array}$ & $\begin{array}{c}\text { 角柱 } \\
\text { Square }\end{array}$ & $\begin{array}{c}\text { 角柱 } \\
\text { Square }\end{array}$ & $\mathrm{Y}$ \\
\hline
\end{tabular}
タイプ Xの形式は、豊国神社や御三家や天 海・崇伝が造営した東照宮、台徳院霊廟や 大鄭院霊廟などにみられ、タイプ Y は神社 にみられる。このことから、タイプ X は霊 廟に用いられた形式、タイプ Y は神社に用 いられた形式ということがわかる。

\section{5-6. 石の間・幣殿と本殿の軒の納まりの} 設計手法

\section{5-6-1. 建物外部}

権現造の軒の納まりの時代的な変化につ いて、大河直躬 13) によると、大崎八幡宮 では石の間の軒が本殿の軒下に入り込み桁 まで達している未熟な方法を用いているが、 久能山東照宮では石の間の本殿寄りの垂木 を衩じ上げて本殿の茅負に接しさせ、日光 東照宮では、垂木を衫じ上げずに石の間の 
垂木を本殿木負までで止めて軒の完全な重なりを避け、さらに大䟮 院霊廟になると、石の間（ママ）の垂木は本殿側も拝殿側も㸚じ上 げて茅負に接するとしている。

まず、石の間型権現造についてみると、石の間及び本殿の軒の接 続にねじ上げの手法を用いているのは久能山東照宮のみで、日光東 照宮と紅葉山東照宮では石の間の垂木を本殿の木負で破風止めとし、 上野東照宮では石の間の軒を本殿の軒と一連としている。東照宮に おいて、石の間と本殿の軒の接続にねじ上げの手法を用いず、石の 間の垂木を本殿の木負あるいは茅負で破風止めにするようになった のは早く、元和 7 年（1621）の水戸東照宮からである。

幣殿型権現造の場合では、鶴岡八幡宮若宮では本殿正面庇の垂木 が幣殿の軒先までで止まっており、幣殿の垂木は本殿軒下に入り込 み、本殿軒の勾配に合わせてねじ上げている（Photo1）。伊賀八幡 宮、六所神社、五社神社、諏訪神社では、幣殿の垂木をねじ上げて 本殿正面庇の軒先で接しさせている。

石の間型権現造と幣殿型権現造の石の間・幣殿と本殿の軒の納ま りを図示した Fig.5 をみると、久能山東照宮に比べ、六所神社、五 社神社は幣殿と本殿の軒の高低差が小さく、㸚じ上げとする茅負の 曲線が小さくゆるやかである。石の間と本殿の軒の高低差が段々と 大きくなる傾向にあった石の間型権現造では、寛永期に入る前から、 石の間の垂木を本殿の木負あるいは茅負で破風止めにする方法に移 っていったが、本殿身舎の正面に庇を亘き下ろす幣殿型権現造では、 幣殿と本殿正面庇の軒の高低差が小さいため、ねじ上げの手法が用 いられていたとみられる。

\section{5-6-2. 建物内部}

石の間も幣殿も、内部に本殿あるいは本殿正面庇の垂木を化粧屋 根裏として見せる（上野東照宮は例外で、本殿軒先を表さず、石の 間一面に折上格天井を張る)。しかし、その垂木先端の処理の仕方を みると、石の間型権現造と幣殿型権現造とで違いがみられる (Fig.6)。

久能山東照宮、日光東照宮は、石の間前方 2 間に折上格天井を張 り、後方 1 間の作り合いには本殿茅負までを石の間内部に表現する。

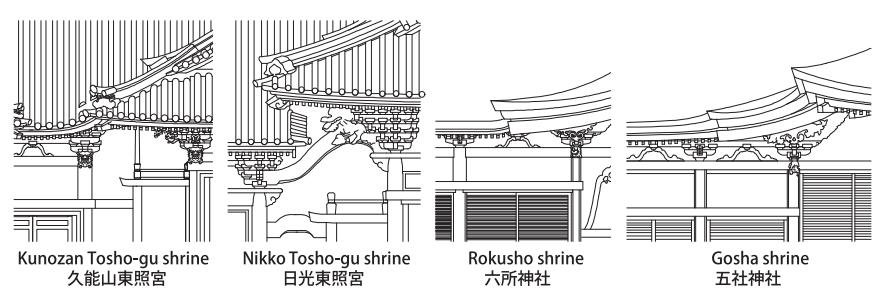

Fig.5 Connecting methods of the eaves of main sanctuary to the eaves of stone hall / votive offering hall.

石の間・幣殿と本殿の外部の軒の納まり

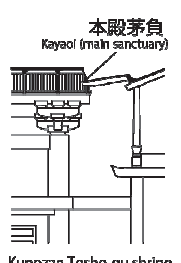

Kunozan Tosho-gu shrine
久能山東照宮

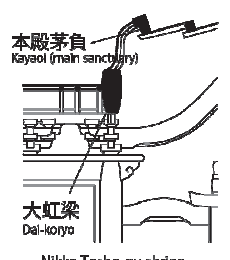

Nikko Tosho-gu shrine
日光東照宮

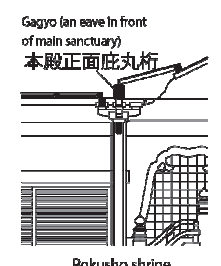

Rokusho shrine
六所神社

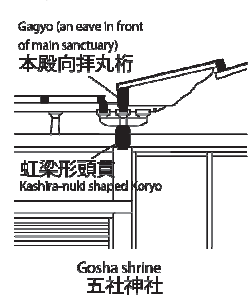

Gosha shrine
五社神社
Fig.6 Connecting methods of the inner eaves of main sanctuary to the ceiling of stone hall / votive offering hall. 石の間・幣殿天井と本殿の内部の軒の納まり
ただし、久能山東照宮では本殿の軒高は石の間天井よりも低く、 石の間天井下に茅負を見せるが、日光東照宮では本殿軒高が石の間 天井よりも高くなる。

幣殿型権現造では、幣殿いっぱいに格天井を張る（諏訪神社では 前室柱まで格天井を延ばす)。幣殿の格天井は、本殿正面庇の柱の上 にある丸桁の下端と同高に張られるため、幣殿側から見ると本殿正 面庇の軒は見えない（Photo2）。また本殿正面庇の垂木は丸桁上部 で切断されるため、軒の先端（茅負）は内部に表れない。

内部に本殿軒先を茅負まで表すか、本殿庇の垂木を途中（丸桁上） で切断するかの違いは、もともと外部空間が塞がれてできた石の間 を持つ石の間型権現造と注 ${ }^{22}$ )、別々の建物である本殿と幣殿とが合 体した幣殿型権現造の成り立ちの違いが、意匠として表れているこ とによるとみられる。

\section{5-7. 小結}

以上、承応期以前に幕府が造営した石の間型権現造と幣殿型権現 造について、権現造を構成する建物の基本構成の違いや、格式表現、 軒の納まりの設計手法の検討を行った。本殿の屋根形式や、拝殿と 石の間・幣殿の様式が異なる両権現造ではあるが、扯殿向拝の幅、 斗栱、柱、瑞垣などを対応させて社殿の格式の差を示していること がわかった。

\section{6. 日枝神社及び根津神社の分析}

\section{6-1. 本殿について}

日枝神社及び根津神社の本殿は、方 3 間入母屋造で、久能山東照 宮をはじめ各地に建立された権現造の東照宮本殿と同規模である。

両社とも東照宮本殿と同様に、前方 1 間通を外陣、後方 2 間を内 陣とする。ただし、東照宮本殿では内陣後方に㕌子を安置するのに 対し、日枝神社・根津神社本殿では内陣後方 1 間をさらに区切り神 殿としている。東照宮本殿の側面は前方 1 間を板唐戸、後方 2 間を 板壁とするのに対し、日枝神社、根津神社では前方 2 間を舞良戸、 後方 1 間を板壁とするといった違いがある。

本殿後方隅柱左右に脇障子を付けるが、これは石の間型権現造に 共通してみられるもので、承応期以前の幣殿型権現造にはみられな い。

縁から下の構成は、石造亀腹に土台立てとし、縁を腰組で支持す る。石造亀腹は、日光東照宮、上野東照宮、紅葉山東照宮で用いら れている。承応期以前の幣殿型権現造の本殿基礎は、切石積や漆喰 亀腹などで、石造亀腹のものはみられない。腰組は、日光東照宮、 上野東照宮、紅葉山東照宮、鶴岡八幡宮若宮、諏訪神社にみられ、 石の間型権現造と幣殿型権現造の両方に用いられている。

以上の意匠的要素を総合すると、日枝神社、根津神社の本殿は、

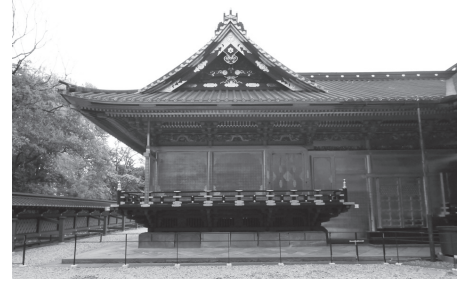

Photo3 The main sanctuary of Ueno Tosho-gu Shrine. 上野東照宮本殿 
内陣内部のつくりや側面の建具が異なるだけで、上野東照宮や紅葉 山東照宮の本殿と同形式といえる（Photo3，Fig.7）。

\section{6-2. 扯殿}

日枝神社・根津神社拝殿の規模は桁行 7 間梁間 3 間で上野東照宮 と同規模であり、最大の規模を持つ日光東照宮に次ぐ大きさである。 正面向拝も、石の間型権現造と同じ 3 間である。

内部の部屋の区画は五社神社・諏訪神社と同様であり、拝殿・幣 殿境は格子戸で仕切る。また、五社神社・諏訪神社よりも栴行が 2 間大きくなったため、拝殿後方 2 間通りの中央の室が横に広くなっ ている。日枝神社では、拝殿後方 2 間通りの柱筋を、本殿の柱筋と 揃えることで、承応期以前の幣殿型権現造の特徵ともいえる幣殿と 拝殿の柱筋のずれを解消している。根津神社の場合は、拝殿の柱筋 は、本殿・幣殿の柱筋とずれたままである。

外周部の柱間装置は、両側面前方 1 間を蔀戸とする以外、五社神 社・諏訪神社と同じである。内部間仕切りは、根津神社は舞良戸を 用いるが、日枝神社は不明である注 23)。

\section{6-3. 幣殿}

日枝神社・根津神社幣殿の間口は本殿正面 3 間と同幅で、桁行各 間の寸法を等間隔としている。根津神社幣殿では拝殿と同じ高さに 頭貫、内法長押、切目長押、土台を通し、舞良戸を入れるなど、扯 殿と同じ立面構成とする。日枝神社は、拝殿と同じ立面構成とする かは古写真から判別できないが、根津神社と同様の立面構成をもつ。 両社とも、伊賀八幡宮以降の幣殿型権現造の幣殿の構成を受け継い でいる。

幣殿と本殿との間にできた作り合いについては、両社で違いがみ られる。日枝神社の作り合いは、1 間分の間隔があり、日光東照宮 や紅葉山東照宮のように本殿と幣殿を海老虹梁で繋いでいる。根津 神社の作り合いは、諏訪神社のように本殿前方の縁幅と等しい。

日枝神社と根津神社は、本殿が入母屋造のため、幣殿内部に本殿 正面庇の柱を通る頭貫や中備を見せるといった承応期以前の幣殿型 権現造の意匠的特徽はみられず、幣殿後方（本殿側より 1 つめの） 柱上の組物から梁間方向に大虹梁が架かっており注 24 )、日光東照宮 のような処理がなされている。

\section{6-4. 斗栱・柱断面形状 · 瑞垣}

斗栱は、日枝神社、根津神社ともに、本殿出組、幣殿・拝殿平三 斗であり、伊賀八幡宮以降の幣殿型権現造と同じ種類である。

柱断面形状は、根津神社では、本殿を円柱、幣殿・拝殿を角柱と し、伊賀八幡宮以降の幣殿型権現造に多い特徴を示すが、日枝神社 では総円柱であり、その他幣殿型権現造と格式の違いを示したとみ られる。

瑞垣形式は、日枝神社、根津神社ともに、正面に瑞垣門を構え、 門両側から瑞垣発し、本殿・幣殿・拝殿を一周する。霊廟の性質を もつ権現造に用いられたタイプ X の形式で、承応期以前の幣殿型権 現造には用いられなかった格上の形式が取り入れられている。

\section{6-5. 幣殿と本殿の軒の納まりの設計手法}

まず外部をみていく。日枝神社は、古写真では判断し辛いが、日 光東照宮や紅葉山東照宮のように、幣殿の軒を本殿の木負や茅負の あたりで破風止めにしているようにみえる。一方根津神社では、破 風止めにする点は日枝神社と同じであるが、本殿と幣殿との間隔が 縁幅しかないためか、幣殿軒が本殿軒下まで入り込んでいる (Fig.7)。

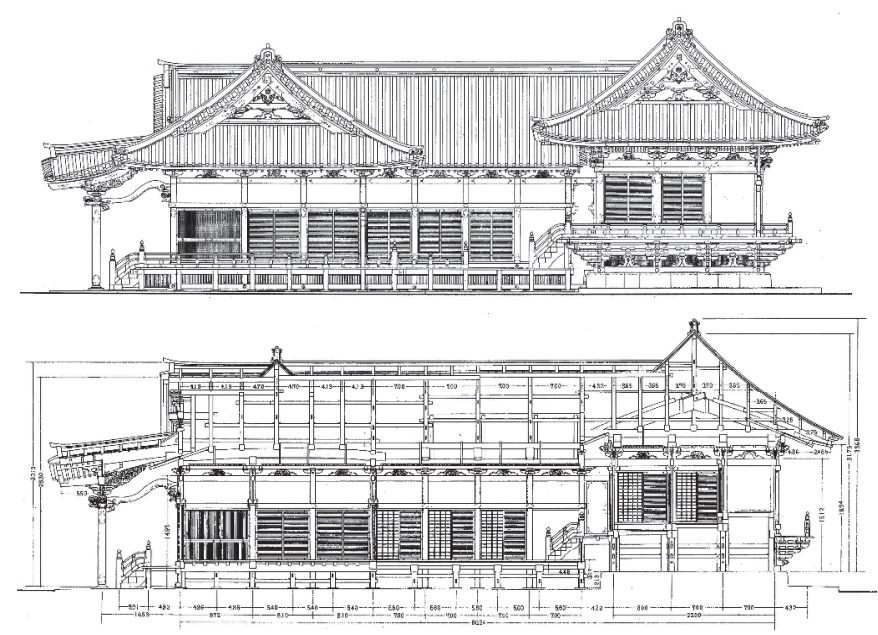

Fig.7 Side elevation and section of Nezu Shrine.

(Reference 9, Drawing 4 and 10.)

根津神社断面図（参考文献 9, 図面 4, 10)

本殿が入母屋造であることで、幣殿と本殿の軒の高低差が大きく なり、垂木をねじ上げずに破風止めにして処理したとみられる。 内部では、日枝神社では、本殿軒下に格天井を張っているため、 本殿の軒を見せない。根津神社では、本殿軒裏を見せるが、作り合 いが本殿前方の縁幅しかないため、幣殿大虹梁上に通る通肘木の上 部で本殿地垂木が切断されている。内部においては、日枝神社と根 津神社で本殿軒の処理の仕方が異なっているが、いずれも石の間の ように本殿軒先を見せないのは、両社が基本的には幣殿型権現造の 形式を受け継いでいることを示していると考えられる。

\section{6-6. 小結}

日枝神社、根津神社の建築は、上野東照宮に匹敵する大きさであ り、承応期以前の幣殿型権現造よりも規模が大きい。組物の種類や、 拝殿、幣殿の平面と意匠は、伊賀八幡宮以降形式化した幣殿型権現 造の構成を受け継いでいるが、東照宮と同形式の本殿を取り入れた り、拝殿向拝を 3 間としたり、瑞垣の形式を社殿を一周するタイプ にするなど、石の間型権現造と同格の形式を採り入れており、承応 期以前の幣殿型権現造よりも格式高い社殿を造ろうとしたことがう かがえる。

日枝神社と根津神社の構成を比較すると、日枝神社では幣殿と本 殿の間の作り合いの部分に東照宮と同様に海老虹梁を架けて両殿を つなぎ、豊かな壁面をつくっているのに対して、根津神社では幣殿 の頭貫を本殿柱まで延ばして繋いだだけの簢素なつくりになってい る。また、日枝神社では総円柱とするのに対し、根津神社では拝殿・ 幣殿を角柱とするなど、根津神社では日枝神社を憚ったと思われる 点が見受けられる。

\section{7. 幕府が権現造を造営した神社について}

幕府が権現造を造営した東照宮以外の神社の事例を、遺構や文献 等をもとに Table4にまとめた。権現造が適用された神社を見ると、 寛永 11 年以前では、江戸総鎮守とされる神田明神や源家の氏神と して崇敬された鶴岡八幡宮、御在城の鎮守・東国の伊勢として崇め られた飯倉神明宮（芝大神宮）といった、江戸とその近郊の有力な 神社の再興が中心である。寛永 13 年以後では 8 事例の内 6 事例が 
将軍の産土神となった神社である。

徳川家光は、寛永 11 年上洛の折、家康の氏神である伊賀八幡宮・ 家康の産土神である六所神社（岡崎）注 25）と、秀忠の産土神である 五社神社・諏訪神社（浜松）注 26）の社殿を新規に大社に造営するよ う命じた。家光は、日光東照宮の寛永造替と併せて、先代・先々代 の将軍の生誕を顕彰することを意図したとみられる。3 章の検討の 中で、寛永元年造営の鶴岡八幡宮若宮だけ細部の構成や様式が他の 幣殿型権現造と異なっており、伊賀八幡宮以降にみられる幣殿型権 現造の形式化が、家光上洛の折に決定した一連の造営を通してなさ れたことがわかる。

『日枝神社史』14）によれば、日枝神社は、城の鎮守、徳川歴朝の 産土神、江戸の産土神・江戸郷の鎮守として、江戸時代の頃から一 般に呼称されていた。もとは川越にあった山王三所の神を太田道灌 が江戸城内に勧請したものと伝えるが、同史によれば貞観元年 （1362）には「江戸郷山王宮」が存在していたといい、古くから江 戸郷の鎮守であった。江戸城が徳川家居城となった頃、家康が城内 にある鎮守の当社を見てこれを尊崇し、紅葉山に社殿を遷し当家歴 朝の産土神としたという（『東照宮御実記附録巻六』、『江戸名所図 会』）。その後貝塚の地一移転し、寛永 7 年に社殿が落成した（『寛 永日記』)。寛永 7 年の社殿は、内藤昌「江戸の都市と建築」8)に詳 しいが、この頃はまだ権現造ではなかったようである。明暦の大火 で焼失したのを機に永田町に遷座し、権現造の社殿となった。幣殿 型権現造の形式に改められたのは、家康または秀忠の産土神となっ た神社の先例に則ったと考えられる。徳川歴朝の産土神となる神社 であることから、六所神社や五社神社、諏訪神社を上回る格式の社 殿が計画されるに至ったとみられ、その結果、「江府第一の宮居」と
いわれる社殿になったと考えられる。

根津神社は、『御府内備考続編』によれば、当社は駒込総鎮守であ り、千駄木に鎮座していたという。現在の社地はかつて甲府宰相 (甲 府藩主德川綱重）の屋敷があったところで、寛文 2 年（1662）に徳 川家宣がそこで生まれた。初宮詣が千駄木の根津神社であったこと から、家宣の産土神となった。宝永元年（1704）家宣が将軍世嗣と して将軍綱吉の養君になったのを機に、翌 2 年家宣が甲府宰相の屋 敷地一根津神社の造営を願い出、翌 3 年建立されたのが現存の社殿 である注 27)。根津神社を産土神とする家宣が将軍となったことで、 慣例の通りに権現造の社殿に改めたといえる。そこで社殿の参考に なったのが日枝神社とみられ、拝殿・幣殿を角柱としたり、幣殿と 本殿の接続を簡素な形としたりすることで歴代将軍の産土神である 日枝神社に配慮する形をとったと推察される。

また、分析には取り挙げていないが、赤坂水川神社は、享保 14 年（1729）家重の産土神につき赤坂今井台へ新規造営が仰せ付けら れたことが『御府内備考続編』注 28) にみえる。本殿は流造本殿とし ている。家重とその父吉宗は紀州徳川家出身であり、秀忠の血を引 いていなかった事情が関係したためか、日枝神社や根津神社を憚っ たと推察される。このように、寛永 13 年以降、将軍の産土神とさ れた神社の社殿を幣殿型権現造とすることが習わしとなっていった ことがわかる。

\section{8. まとめ}

本稿は、日枝神社と根津神社の建築について、承応期以前の石の 間型権現造及び幣殿型権現造との比較から建築的特徵を明らかにし た上で、幕府が権現造を造営した神社について歴史的に考察し、以

Table4 Shrines other than Toshogu built in Gongen-style constructed by Tokugawa Shogunate*.

幕府が権現造を造営した東照宮以外の神社一覧

\begin{tabular}{|c|c|c|c|c|c|c|c|c|c|c|}
\hline 名称 & 所在地 & 建立年 & 現存 & 分類 & 拝殿室内 & 社格 & 願主 & 大工 & 備考 & 典拠 \\
\hline 神田明神社 & 東京都千代田区 & 元和 $3 \cdot 1617$ & $x$ & $\begin{array}{l}\text { (本殿流造：元和) } \\
\text { (本殿入母屋造： } \\
\text { 承応) }\end{array}$ & $\begin{array}{l}\text { 三室 } \\
\text { (天明期) }\end{array}$ & \begin{tabular}{|l} 
(秀忠曰)城下鎮 \\
守(武陽神田新 \\
廟記) \\
江戸総鎮守(神田 \\
明神御由緒書、 \\
寛文以降棟札写)
\end{tabular} & 徳川家治 & $\left|\begin{array}{l}\text { 鈴木長次 } \\
\text { 片山国久 }\end{array}\right|$ & 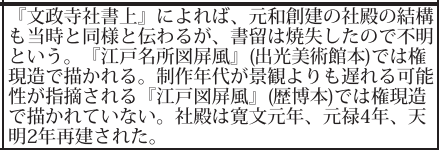 & $\begin{array}{l}\text { 御府内備考続編, } \\
\text { 江戸名所図会 }\end{array}$ \\
\hline 鶴岡八幡宮若宮 & 神奈川県鎌倉市 & 寛永 $1 \cdot 1624$ & 0 & 幣殿型・流造 & 単室 & 源家氏神 & 徳川秀忠 & 鈴木長次 & & 棟札 \\
\hline 鶴岡八幡宮上宮 & 神奈川県鎌倉市 & 寛永 $1 \cdot 1624$ & $x$ & $\begin{array}{l}\text { 幣殿型・流造 } \\
\text { ※文政11再建 }\end{array}$ & 単室 & 源家氏神 & 徳川秀忠 & 鈴木長次 & 文政11年（1828）再建の社殿現存 & $\begin{array}{l}\text { 鶴岡八幡宮絵図(享保17年), } \\
\text { 鶴岡咸八幡呂御造営記 }\end{array}$ \\
\hline 飯倉神明社 & 東京都港区 & 寛永11· 1634 & $x$ & $\begin{array}{l}\text { (本殿入母母屋造ま } \\
\text { たは入母洷造向 } \\
\text { 拝付 : 寛永) } \\
\text { (本殿切妻造また } \\
\text { は流造 : 安永) }\end{array}$ & - & \begin{tabular}{|l|} 
御在城之御鎮守 \\
・東国之伊勢 \\
(御府内備考続 \\
編)
\end{tabular} & 徳川家光 & 鈴木長次 & 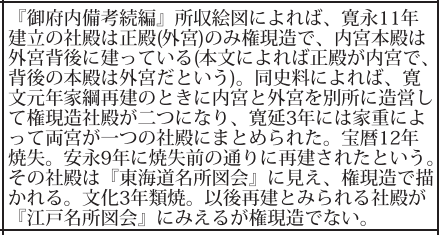 & 御府内備考続編 \\
\hline 伊賀八幡宮 & 愛知県岡崎市 & 寛永13·1636 & 0 & 幣殿型・流造 & 三室 & 家康氏神 & 徳川家光 & 鈴木長次 & & 棟札 \\
\hline 六所神社 & 愛知県岡崎市 & 寛永13・1636 & 0 & 幣殿型・流造 & 三室 & 家康産土神 & 徳川家光 & 鈴木長次 & & 梀札 \\
\hline 五社神社 & 静岡県浜松市 & 寛永18·1641 & x & $\begin{array}{l}\text { 幣殿型・八母屋 } \\
\text { 造向拝付 }\end{array}$ & 三室 & 秀忠産土神 & 徳川家光 & 木原義人 & & $\begin{array}{l}\text { 梀札写(『五社神社・諏訪神 } \\
\text { 社 社殿等修理関係資料』) }\end{array}$ \\
\hline 諏訪神社 & 静岡県浜松市 & 寛永18·1641 & $x$ & 幣殿型・流造 & 三室 & 秀忠産土神 & 徳川家光 & 木原義久 & & $\begin{array}{l}\text { 梀札写(『五社神社・諏訪神 } \\
\text { 社 社殿等修理関係資料』) }\end{array}$ \\
\hline 三芳野神社 & 埼玉県川越市 & 明磿 $2 \cdot 1656$ & 0 & 幣股型 · 入母屋造 & 単室 & 川越城鎮守 & 徳川家網 & 木原義久 & 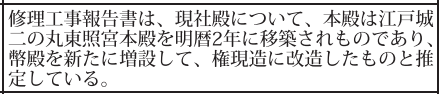 & 棟札, 修理工事報告書 \\
\hline 日枝神社 & 東京都千代田区 & 万治 $2 \cdot 1659$ & $x$ & 幣殿型 · 入母屋造 & 三室 & \begin{tabular}{|l} 
御城内鎮守 \\
徳川歴朝の産 \\
土神 \\
江戸の産土神 \\
汇戸乡鄉の鎮守
\end{tabular} & 德川家綱 & \begin{tabular}{|l|} 
鈴木長恒 \\
木原義永
\end{tabular} & & $\begin{array}{l}\text { 『日枝神社史』，『新版戦 } \\
\text { 災等による焼失文化財』 }\end{array}$ \\
\hline 根津神社 & 東京都文京区 & 宝永 $3 \cdot 1706$ & 0 & 幣殿型・ 入母屋造 & 三室 & 家宣産土神 & 徳川網吉 & 村松宗章 & & 御府内備考続編梀札写 \\
\hline 赤坂水川神社 & 東京都港区 & 享保15・1730 & 0 & 幣殿型・流造 & 単室 & 家重産土神 & 徳川吉宗 & 村松棟明 & & 御府内備考続編棟札写 \\
\hline
\end{tabular}

* This table omit English sentences in order annotate long text in the remarks column 


\section{下の点を明らかにした。}

東照宮において典型的な石の間型権現造と、東照宮以外の神社に おいて典型的な幣殿型権現造について、承応期以前の事例を比較し、 両者の様式が異なっていることを示した。従来、幣殿型権現造にみ られる本殿を流造とする形式は東照宮を憚ったといわれているよう に、幣殿型権現造は向拝の幅、斗栱、柱、瑞垣においても東照宮よ りも簡略な形式を用いていることがわかった。また、徳川家光の上 洛の折に決定した家康・秀忠の氏神あるいは産土神とされる神社の 一連の造営で、幣殿型権現造の形式化がなされたことを示した。

日枝神社及び根津神社は、幣殿・拝殿の様式や組物は先規の伊賀 八幡宮以降の幣殿型権現造の形式に則っている一方、本殿は東照宮 と同形式の方 3 間入母屋造とし、また向拝の幅や瑞垣等の形式を石 の間型権現造と同格としていることを明らかにした。日枝神社と根 津神社の比較では、根津神社には日枝神社を憚ったと思われる点が 見受けられた。

以上のことから、日枝神社の建築は、徳川歴朝の産土神として六 所神社や五社神社、諏訪神社を上回る格式の社殿とするため幣殿型 権現造の中に東照宮の建築の格式表現を取り入れた形式であり、江 戸を代表する社殿となったこと、根津神社は将軍家宣の産土神とし て日枝神社の建築形式に則った社殿でありながら日枝神社に配慮し た建築表現をもつことを示す建築として評価できる。

本稿の分析を通じて、家綱治世以降、本殿・拝殿間の建物と本殿 の組合せが形式化していた権現造の構成が崩れていく背景の一端を 明らかにすることができたほか、幕府大工による権現造の格式表現 の具体像とその展開を明らかにすることができた。

しかし、幣殿型権現造において日枝神社・根津神社よりも以前に 入母屋造の本殿をもっていた五社神社（向拝付）や三芳野神社の位 置付けをどのように捉えるか、本稿では触れることができなかった ため、今後五社神社や三芳野神社についても考察が必要になると考 える。

\section{参考文献}

1) Ito, C.: Depelopment of Japanese Shrine Architectute (last volume), Journal of Architecture and Building Acience, Vol. 15, No. 174, 1901.6 伊東忠太: 日本神社建築の発達(下), 建築雑誌, 第 15 巻, 第 174 号, 1901. 6

2) Materials Related to Repairing the Main Buildings of the Gosha Shrine/ Suwa Shrine, Compilation of the main texts, Tokyo National Museum, 1996

五社神社・諏訪神社 社殿等修理関係資料 本文篇, 東京国立博物館, 1996

3) Materials Related to Repairing the Main Buildings of the Gosha Shrine/Suwa Shrine, Compilation of plates, Tokyo National Museum, 1996

五社神社・諏訪神社 社殿等修理関係資料 図版篇, 東京国立博物館, 1996

4) Fumoto, K.: Architecture of Kanazawa Tosho-gu Shrine, Reserch on the Kanazawa Tosho-gu Shrine (Ozaki Shrine), Kanazawa castle research laboratory, 2006

麓和善：金沢東照宮の建築，金沢東照宮（尾崎神社）の研究，金沢城研究 調査室, 2006

5) Eizou, I.: Shrine and Mausoleum, Shogakukan, 1968.10

稲垣栄三：神社と霊廟, 小学館, 1968.10

6) Historic Preservation Sites of Tokyo Prefecture, Koyo, 1919.6 東京府史蹟, 洪洋社, 1919.6

7) Tokyo city: Historic Preservation Sites of Tokyo, Kouseikaku, 1925.4 東京市：東京の史蹟, 厚生閣, 1925.4

8) Naitoh, A.: Special Volume on Folding Screens with Edo Scenes: Urban and Architecture in Edo, Mainichi Newspapers, 1972

内藤昌：江戸図屏風別巻 江戸の都市と建築, 毎日新聞社, 1972

9) Restoration Work (Due to War Damage) Report on the Main Shrine, the Votive Offering Hall and the Worship Hall of Nezu Shrine (The reconstruction Due to War Damage), Nezu Shrine, 1960 重要文化財根津神社本殿幣殿拝殿（戦災復旧）修理工事報告書, 根津神社, 1960

10) Murakami, J.: Phraseology of Composite Building in Structural Type: Gongen-zukuri and Ryosage-zukuri, JACAM report, No. 125, 2016.7 村上訒一: 構造形式における複合社殿の表記一権現造と両下造, 文建協通 信，第 125 号, 2016.7

11) Agency for Cultural Affairs ed. New Edition of the Cultural Assets Lost in Fires Dew to War Damage etc., Ebisukosyo Publication, 2003 文化庁: 新版 戦災等による焼失文化財 20 世紀の文化財過去帳, 戒光祥出 版, 2003

12) Yamazawa, M.: Establishment of Nikko Tosho-Gu: The Shogon of Early Modern Mt. Nikko and the Worship and the Organization, Shibunkaku, 2009.2

山澤学：日光東照宮の成立 近世日光山の「荘厳」と祭祀・組織, 思文閣, 2009.2

13) Ohkawa, N.: Gongen-Style Building and Architectural Sculpture, ARS BUDDHICA, No. 170, The Mainichi Newspapers, 1987.1 大河直躬：権現造りと建築彫刻，佛教芸術，第 170 号，毎日新聞社， 1987. 1

14) History of Hie Shrine, Service Association of $500^{\text {th }}$ Anniversary of Enshrinement of Hie Shrine, 1979.1 日枝神社史，日枝神社御鎮座五百年奉賛会，1979.1

15) Third Collection of Fundamental Materials of the History of Japanese Architecture for Main Buildings III, Chuokouronbijutsu, 1976 日本建築史基礎資料集成三 社殿 III, 中央公論美術出版, 1976 年

16) Restoration Work Report part 1, on Kunozan Tosho-gu Shrine (important Cultural Property): the first term and second term, Repair Committee of Kunozan Tosho-gu Shrine (important Cultural Property), 1969

重要文化財久能山東照宮 第一期第二期 修理工事報告書第一集, 重要文化 財久能山東照宮修理委員会, 1969

17) Shrine and Temple Architecture in the Modern Ages of Kanagawa, Kanagawa Prefecture Education Board, 1993 神奈川県の近世社寺建築, 神奈川県教育委員会, 1993

18) Restoration Work Report on the Main Sanctuary, the Stone Hall, and the Worship Hall of Tosho-gu Shrine (National Treasure), Association for the Preservation of the Nikko World Heritage Site Shrines and Temples, 1968

国宝東照宮本殿 - 石之間 - 拝殿修理工事報告書, 日光二社一寺文化財保存 委員会, 1968

19) Ohkawa, N.: Tosho-gu Shrine, Kajima Institute Publishing, 1971 大河直躬：東照宮, 鹿島研究所出版会, 1971

20) Restoration Work Report on the Main Buildings of Tosho-gu Shrine (important Cultural Property), Tosho-gu Shrine, 1966 重要文化財東照宮社殿修理工事報告書, 東照宮, 1966

21) Restoration Work Report on the Main Buildings of Iga-Hachimangu Shrine (important Cultural Property), Repair Committee of Iga Hachiman-gu Shrine (important Cultural Property), 1969 重要文化財伊賀八幡宮社殿修理工事報告書, 重要文化財伊賀八幡宮社殿修 理委員会, 1969

22) Restoration Work Report on the Main Sanctuary, the Votive Offering Hall, the Worship Hall, Jingu-Sho, and the Two-Storied Gate of Rokusho Shrine (important Cultural Property), Repair Committee of Rokusho Shrine buildings (important Cultural Property), 1977 重要文化財六所神社本殿 - 幣殿 - 捧殿 - 神供所 - 楼門修理工事報告書, 重 要文化財六所神社社殿修理委員会, 1977

23) New Revisions of the Edo Meisho Zue, Chikuma Gakugei, 1996 新訂 江戸名所図会, ちくま学芸文庫, 1996

24) Historical Materials on the Shrines in Tokyo, Vol. 1, Tokyo-Jinjacho, 1967

東京都神社史料，第一輯，御府内備考続編 神社部，東京都神社庁， 1967 
注

注 1）石井敬吉「日本佛寺建築沿革略（第九十四號の續き）」（建築雑誌，第 8 巻, 第 95 号, 1894）、塚本靖「日光廟建築裝飾概論」（建築雑誌，第 11 巻, 第 124 号, 1897) では、東照宮の建築である権現造とは、神仏混淆の 造りとしている（塚本は、大缺院霊廟は専ら仏式に従うとして権現造とは 別にしている）。その後伊東忠太は「日本神社建築の発達（下）」（参考 文献 1) において、権現造の形式を「本殿と扯殿とを中殿を以て連結し、 これを一塊の建築物としたものであると解釈する」として権現造の造形の 特徴を述べるとともに、神社建築における神仏混淆式の中の一種の形式と して位置づけている。伊東の分類に従えば、伊東は、流造や重層入母屋造 の本殿をもつものや、本殿・洋殿間の建物の床を拝殿と同じ高さに張るよ うな、東照宮以外の神社や徳川家霊廟も権現造に含んでいる。

注 2）伊東忠太は、慶長 12 年（1607）再建の北野天満宫のように据殿の左右 に楽の間を設けたより複雑な形態の権現造を八棟造と称している。しかし、 『義演准后日記』慶長 3 年九月七日条の「大仏東山に八棟作りの社頭建つ、 北野社のごとしとうんぬん」という記事が指寸慶長 12 年再建前の北野天満 宮の社殿（洛中洛外図）には、楽の間がなく、典型的な権現造の形態であ った。

注 3）濱島正士「本殿を流造とした複合社殿について」（参考文献 2、p18-20） では、本殿を流造とする形式の複合社殿を、入母屋造の形式と区別して「淮 権現造」と呼んでいる。

注 4) 前掲書 3)

注 5）鎌倉時代の絵巻には、三島大社・美作国一宮（『一遍聖絵』）や、防 府天満宮（『松崎天神縁起』）など、本殿・幣殿あるいは舞殿・楼門の三 棟を接近して建てた石清水八幡宮の社頭を省略したような配置をもつ神社 が描かれている。また、本殿に縦扯殿を接近して建てた社殿が、山陽道西 部や北九州など中心に現存している。稲垣栄三は、妻入の建物は本殿に接 して置き、幣殿として用いるのが妥当で、（石清水八幡宮のような）着座 の場所であった回廊が失われたとき、幣殿をそのままの形で抨殿に転化し たのが縦找殿ではなかららかと推察している。（参考文献 5)

注 6）伊賀八幡宮、諏訪神社、飯倉神明社では、家光治世に権現造の社殿が 建立された当時、相殿に家康（諏訪神社はさらに秀忠）を勧請したことが 由緒等の記録に残っている。

注 7）増上寺や寛永寺に造営された徳川家の仏式霊廟。

注 8) ここでいう本殿・拝殿間の呼称と構造形式は、村上訒一（参考文献 10) の意見に従っている。

注 9）永井規男「五社神社・諏訪神社両社の社頭の構成と本社の形式」（参 考文献 9、p62-68)

注 10）永井規男（前掲書 9）は五社神社本殿前面についた 3 間の向拝につい て、「向扯は板床となり両側面に舞良戸を引違いに建てるので、一般の向 洋とは異なり本殿の前室的な空間になっている。」とする。永井が以降文 章でも向捧と呼んでいるのに従い、本稿でも向捧と呼ぶこととする。

注 11）三芳野神社の建築について、修理工事報告書は、明暦 2 年移築の江戸 城二の丸東照宮の本殿と寛永造営の拝殿との間に幣殿を増設して連結した と推定している。もとは権現造ではない建物を合体したものとみられるこ とから、本稿の分析対象からはずした。しかしながら、日枝神社よりも先 に、幣殿をもつ権現造の本殿に東照宮の建築を持ってきた可能性があるこ とは注目される。

注 12）前掲書 9)

注 13）日光東照宮拝殿の両脇の部屋はそれぞれ、将軍着座の間（東側）、法 親王着座の間（西側）と呼ばれている。山澤学（参考文献 12）によれば、 寛永 13 年の家康 21 回神忌法要で、将軍着座の間に家光と御三家、法親王 着座の間に明正天皇の栜使と後水尾上皇の院使が着座したことを明らかに している。将軍着座の間と法親王着座の間は、将軍や栜使の座所として計 画的に設けられたと考えられ、その証に、将軍着座の間、法親王着座の間 では、二重折上格天井としたり、壁面と天井を唐木象嵌で埋め尽くしたり するなど、抨殿中央の部屋よりも華美な造作となっている。一方、伊賀八 幡宮や六所神社、五社神社、諏訪神社などでは、择殿両脇に区画されてい る部屋と中央の部屋の造作は同じである。洋殿両脇に区画されている部屋
は日光東照宮のように将軍が着座する部屋として設けられたものではない とみられ、実際にどのような用途で設けられたかは不明である。

注 14）台徳院霊廟、崇源院霊牌所、大鄭院霊廟といった御霊屋も拝殿が単室 となっている。

注 15）『建築大辞典』では〔造り合い〕とは、「宇佐神宮の本殿のように二 つの殿堂の屋根の出会う部分。」とし、『古建築辞典』では「二つの建築 物が、軒または妻を接近して建つときの中間部分をいう。」としている。 本稿では、石の間前方 2 間の構造あるいは幣殿の構造と、本殿の構造とが 接近して建つときの中間部分を便宜的に〔作り合い〕と呼ぶこととする。

注 16）幣殿の桁行の柱間が等間隔なのは、縦拝殿の建築の流れを波んでいる ことによるものと思われる。

注 17）前掲書 9)

注 18）ただし、御霊屋に関しては、村上（参考文献 10）が、「日光東照宮な どと比べれば、本殿と拝殿の独立性が高く、この間の繋の間は、梁間が狭 くて本殿と拝殿を繋ぐ廊下になるといった特徵があり」、繋の間の構造は、 「独立した桁行三間、梁間一間の建物で、本殿と扯殿とは、それぞれ海老虹 梁で繋ぐ」と指摘するように、その立面構成は拝殿と同じつくりではない。

注 19）鶴岡八幡宮若宮の本殿身舎及び拝殿には、蔀戸は用いられていない。 注 20）参考までに、久能山東照宮、日光東照宮、上野東照宮は、本殿・石の 間・拝殿の 1 枝寸法が一致している。ただし、石の間析行において拝殿・ 石の間軒接続部や本殿・石の間軒接続部に位置する柱間では枝割が成立し ないことがある。

注 21）五社神社・諏訪神社では本殿正面庇の頭貫が虹梁型になっている。

注 22）石の間内部に本殿軒先を表現することで、石の間を壁や屋根で塞ぐ前 の状態が外部空間であったことを意匠として示していると考えられる。

注 23）日枝神社の内部間仕切りは、建具を入れる装置はあるが、建具の種類 は不明である。また、前方 1 間通りと後方 2 間中央の室境には犬防を入れ る。(参考文献 11)

注 24）ただし、幣殿側から見ると大虹梁のほとんどは幣殿格天井で隠れてし まい、大虹梁下部のわずかな部分しか見えない。

注 25) 安永 9 年『伊賀八幡宮御由緒書』(愛知県西尾市立図書館岩瀬文庫蔵) (参考文献 2 所収)

「御累代御尊敬之社頭、殊更東照宮御氏神之申、旁以小社二而者不可然言上 可被成趣御座候、則伊豆守殿奉二而御造営被 仰出新大社二御建立被遊 候、」

『御勝手帳』第 23 冊所収慶応元年 11 月願出（参考文献 2 所収）

「東照宮様御産生神之御由緒二付、寛永年中、大鄭院様御上洛之節、六所御 社頭新規大社二御造営被為遊、」

注 26）明和四年由緒書上（東京大学史料編纂所蔵『県社五社神社創建由緒沿 革之記』）（参考文献 2 所収）

$\lceil$ 大唒院様宽永十一年戌御上洛之御時御社参被為遊、御詠歌御座候由申伝候、 御社領百石之御朱印頂戴仕候、為御先例又新規二御社頭御造営被為仰付」、 諏訪神社御由緒書（浜松市立図書館蔵『村社諏訪神社創立由緒沿革之記』） (参考文献 2 所收)

「同（寛永）十一年七月二日大猷院様御上洛之節、台徳院様御開運依為御産 神被遊御参詣、御太刀 御奉納幣祝詞御神楽、畢而御詠歌（中略）

同月廿四日御能興行被仰付江戸より役者百七十人参着相勤之、御直二御見 分ノ上宮地常寒山御改御造営被仰付」

注 27）根津権現御由緒書（『御府内備考続編』所収）

「則権現之儀者文昭院（家宣）様御産土神御座候、其後宝永元申年十一月、 文昭院様御事、常憲院様御養君被為成二付、宝永二西年四月廿五日日光門 主御方え為上使稲垣対馬守 $コ$ 以被仰進候者、根津権現之儀大納言様依御願、 甲府様御屋舗之権現社御創建被為遊度之旨被仰進候、宝永二西年四月御造 営被仰出、」

注 28）「有徳院様 惊信院様御産神二被為在候二付、同年（享保 14）九月廿 八日別当大乗院被為召於柳之間、御老中寺社奉行列座二而、水川御社赤坂 今井台え新規御造営被仰付候段、」 


\title{
A STUDY ON ARCHITECTURAL COMPOSITION AND ITS POSITION OF HIE SHRINE AND NEZU SHRINE
}

\section{Chiaki KATOH $^{* 1}$ and Yutaka SHIGEEDA ${ }^{* 2}$}

\author{
${ }^{* 1}$ Research Assist., Dept. of Architecture, College of Science \& Technology, Nihon Univ., M.Eng. \\ ${ }^{* 2}$ Prof., Dept. of Architecture, College of Science \& Technology, Nihon Univ., Dr.Eng.
}

The building of Hie shrine (built in 1659, destroyed by fire in 1945) was built in Gongen-style. The building of Nezu shrine (built in 1706) is in the same style as Hie shrine. Usually, in the Gongen-style built in the shrines other than Tosho-gu before the Shoo era, it often has Nagare-zukuri (asymmetrical gable roof) style main sanctuary of which status is lower than Tosho-gu. In contrast, the main sanctuaries of both shrines have same style as Tosho-gu although they are common shrine. However, No this fact have been pointed out.

This paper pays attention to the building of Hie shrine was also known as the most luxurious shrine building in Edo since the Edo era, through comparison with Gongen-style built in Tosho-gu and the shrines other than Tosho-gu before the Shoo era, clarify that the characteristics of Hie shrine and Nezu shrine. And we considered that historical context of the shrines other than Tosho-gu built in Gongen-style constructed by Tokugawa Shogunate.

Through this analysis, we establish the following facts:

1. Before the Shoo era, the votive offering hall type Gongen-style has simplified form compared to the stone hall type Gongen-style, in the width of eave in front of main sanctuary, sectional shape of column, and innermost fence type.

2. The buildings of Hie shrine and Nezu shrine are basically given in votive offering hall type Gongen-style before the Shoo era. But, the main sanctuaries, the eave in front of main sanctuary, and innermost fence type, are ranked as the stone hall type Gongen-style.

3. The votive offering hall type Gongen-style was brought into use in the shrines which are treated as a certain Tokugawa Shogun's ubusunafami (guardian deity of their birthplace). Especially Hie shrine was also placed as the successive Tokugawa Shogun's ubusunagami.

The authors conclude with Hie shrine is the building that adopting status expression of the stone hall type Gongen-style in the votive offering hall type Gongen-style, as the successive Tokugawa Shogun's ubusunagami, and it became the most luxurious shrine building in Edo. Also, The building of Nezu shrine is following the building of Hie shrine, and modest composition compared to Hie shrine as the Shogun Ienobu's ubusunagami.

A portion of back ground to collapse of combination of main sanctuary and the building between main sanctuary and worship hall has been brought to light. And the status expression example of Gongen-style by official carpenter of Tokugawa shogunate is clarified. 